\title{
Hygienic-sanitary quality and effect of freezing time and temperature on total antioxidant capacity of human milk
}

\section{Qualidade higiênico-sanitária e efeito do tempo e da temperatura de congelamento na capacidade antioxidante total do leite humano}

\author{
Lilian Maria Peixoto Lopes ${ }^{1}$, Jaísa Oliveira Chaves ${ }^{2 *}$ (D), Luciana Rodrigues da Cunha1, \\ Maria Cristina Passos ${ }^{1}$, Camila Carvalho Menezes ${ }^{1}$
}

${ }^{1}$ Universidade Federal de Ouro Preto (UFOP), Departmento de Alimentos, Ouro Preto/MG - Brasil ${ }^{2}$ Universidade Estadual de Campinas (UNICAMP), Faculdade de Ciências Aplicadas, Limeira/SP, Brasil

*Corresponding Author: Jaísa Oliveira Chaves, Universidade Estadual de Campinas (UNICAMP), Faculdade de Ciências Aplicadas, Rua Pedro Zaccria, CEP: 13484-350, Limeira/SP - Brasil, e-mail: jaisa.chaves@gmail.com, j229835@dac.unicamp.br

\begin{abstract}
Knowledge of the hygienic-sanitary quality of raw human milk helps to establish the best storage conditions for the preservation of its nutritional and functional components. Therefore, this study aimed to evaluate the hygienicsanitary quality of human milk extracted at the mothers' homes, and to analyze the effect of freezing time and temperature on the milk's total antioxidant capacity. Milk of five mothers was evaluated individually for Staphylococcus aureus, total aerobic mesophilic counts, mold and yeasts, total and thermotolerant coliforms. The milk pool was stored at $-8{ }^{\circ} \mathrm{C},-18^{\circ} \mathrm{C}$ and $-40^{\circ} \mathrm{C}$ for $2,4,8$ and 15 days and analyzed for the total antioxidant capacity by the 2,2-diphenyl-1-picrylhydrazyl free radical and 2,2-azino 3-ethylbenzothiazoline-6-sulfonic acid scavenging methods. The microbiological analyses of the raw human milk samples indicated counts of all the studied microorganisms above the safe limits. Related to the effect of freezing time and temperature on total antioxidant capacity, it was concluded that, regardless of the freezing temperature, a significant reduction occurred on total antioxidant capacity over time and that the lower the storage temperature, the greater its total antioxidant activity.
\end{abstract}

Keywords: Bioactive components; Free radical ABTS; Free radical DPPH; Hygienic-sanitary quality; Human milk; Storage.

\section{Resumo}

É relevante conhecer a qualidade higiênico-sanitária do leite humano cru e estabelecer as melhores condições de armazenamento para a preservação de seus componentes nutricionais e funcionais. Portanto, o objetivo deste estudo foi avaliar a qualidade higiênico-sanitária do leite humano extraído no domicílio de mães e analisar o efeito do tempo e da temperatura de congelamento na capacidade antioxidante total desse leite. O leite de cinco mães 
foi avaliado individualmente para Staphylococcus aureus, contagem total de mesófilos aeróbios, bolores e leveduras, coliformes totais e termotolerantes. As amostras foram armazenadas a $-8{ }^{\circ} \mathrm{C},-18{ }^{\circ} \mathrm{Ce}-40{ }^{\circ} \mathrm{C}$ por $2,4,8$ e 15 dias, e analisadas quanto à capacidade antioxidante total pelo radical livre 2,2-difenil-1-picrilhidrazil e por métodos de eliminação do ácido 2,2-azino 3-etilbenzotiazolino-6-sulfônico. As análises microbiológicas das amostras de leite humano cru indicaram contagens de todos os microrganismos estudados acima dos limites considerados seguros. Em relação ao efeito do tempo de congelamento e da temperatura na capacidade antioxidante total, concluiu-se que, independentemente da temperatura de congelamento, houve redução significativa ao longo do tempo, e quanto menor a temperatura de armazenamento, maior a atividade antioxidante total do leite.

Palavras-chave: Componentes bioativos; Radical livre ABTS; Radical livre DPPH; Qualidade higiênico-sanitária; Leite humano; Armazenamento.

\section{Introduction}

Human milk (HM) provides all essential nutrients for newborns (NB), including growth factors, bioactive components, and immune factors (Ruiz et al., 2017). However, milk is a good medium for the growth of many microorganisms, thereby making it a possible means of transmission of microbial infections when not properly collected, processed, and stored (Obiajuru et al., 2017). Despite having antimicrobial properties that delay the decomposition caused by the primary microbiota, the HM has little efficacy against secondary contaminants from the environment, utensils and mothers (Grazziotin et al., 2010). Thus, it must be handled under hygienic-sanitary conditions suitable to avoid contamination by pathogens (Novak et al., 2008).

The exposure of newborns to pathogenic bacteria present in contaminated raw HM can lead to diarrhea, neonatal sepsis, meningitis, and necrotizing enterocolitis (Haiden et al., 2016, Keim et al., 2013). Moreover, high levels of contaminants in raw HM leads to decreased defense factors and bioavailability of nutrients since the contaminant microbiota uses these nutrients for survival (Novak \& Cordeiro, 2007).

HM contains bioactive compounds that protect neonates from the hypoxic environment at birth (Tsukahara 2007), which lead to increased free radical production and oxidative stress (Friel et al., 2004). Among them, antioxidants are superoxide dismutase, catalase, glutathione peroxidase, coenzyme Q10, lactoferrin (Lindmark-Månsson \& Åkesson, 2000), vitamins E and C, retinol and $\beta$-carotene (Tijerina-Sáenz et al., 2009).

The current lifestyle of working mothers may hinder breastfeeding. However, in circumstances where the mother is separated from the newborn or when it is unable to breastfeed, it is necessary to encourage the extraction and storage of HM (Eglash \& Simon, 2017, American Academy of Pediatrics, 2003).

According to the Ministry of Health (Brasil, 2015), the breastfeeding woman must empty the breasts by extracting her milk at regular intervals. The milk can be refrigerated for 12 hours or frozen for 15 days in a sterilized glass bottle with plastic cap. When the milk is offered to the infant, the bottle should be thawed in a water bath and offered with a cup or spoon. Whenever the mother is with the infant, she should offer her breast to maintain lactation.

In 2008, the National Health Surveillance Agency released the document entitled: "Human Milk Bank: Operation, Prevention and Risk Control/National Health Surveillance Agency. - Brasilia: Anvisa, 2008", which contains the Brazilian microbiological standards, with more information about the handling of human milk.

In view of the increasing number of mothers who need to store the milk to be offered to the baby in their absence, it is necessary to check hygienic-sanitary control during the extraction procedures and establish the best storage conditions to preserve its functional components, which will reflect on the health of the infant. Therefore, the study aimed to evaluate the hygienic-sanitary quality and to verify the effects of freezing time and temperatures on the total antioxidant capacity of HM. 


\section{Material and methods}

\subsection{HM collection procedures}

The study counted with the participation of all donors (5) registered at the human milk bank (HMB) of the Hospital Santa Casa de Misericórdia in Ouro Preto in 2016. The donors extracted $50 \mathrm{~mL}$ milk in their homes in sterilized bottles $\left(121^{\circ} \mathrm{C} / 20\right.$ minutes), and stored under refrigeration until the time of collection, according to the Handbook "Human Milk Bank: Operation, Prevention and Control of Risks" (Brasil, 2008). All bottles were transported in isothermal boxes to maintain the temperature until they reached the laboratories of the School of Nutrition of the Federal University of Ouro Preto, where the analyses were carried out. The present study was approved by the Research Ethics Committee of the Federal University of Ouro Preto under the number CAAE 50031315.9.0000.5150.

\subsection{Analysis of hygienic-sanitary quality of milks}

Each raw milk sample was individually analyzed for counts of Staphylococcus aureus by inoculating appropriate dilutions of the homogenate in Petrifilm ${ }^{\mathrm{TM}}$ STX (Association of Official Analytical Chemists, 2019). Petrifilm products are AOAC International (Rockville, MD, USA) approved reference methods for use in the dairy industry and have been used to analyze bacteria in human milk (Berenhauser et al., 2018; Perrin et al., 2018; Meng et al., 2016; United States Food and Drug Administration, 2015; Ding et al., 2015).

Total and thermotolerant coliforms, were measured with the Most Probable Number Technique (MPN) (Brasil, 2019). Fungi and yeasts and total aerobic mesophilic bacteria were measured by the standard plate counting method, by surface plating (spread plate) using PCA and BDA agar, respectively. The plates were incubated at $37{ }^{\circ} \mathrm{C}$ for 24 to 48 hours (aerobic mesophiles) (Laird et al., 2004), and $25^{\circ} \mathrm{C}$ for 5 days (mold and yeast) (Wehr \& Frank, 2004).

\subsection{Evaluation of the effect of freezing time and temperatures on the total antioxidant capacity of human milk}

The five HM samples were pooled, obtaining 13 aliquots, the first consisted of raw HM analyzed soon after the extraction. The other aliquots were subjected to freezing at different temperatures $\left(-8^{\circ} \mathrm{C},-18^{\circ} \mathrm{C}\right.$ and $-40{ }^{\circ} \mathrm{C}$ ) and different times ( 2 days, 4 days, 8 days, and 15 days).

The determination of the total antioxidant capacity was carried out by the methods of scavenging the 2,2 - azino 3 - ethylbenzothiazoline - 6 - sulfonic acid free radical (ABTS) and the 2,2 - diphenyl - 1 picrylhydrazyl (DPPH) free radical. To determine the DPPH free radical scavenging activity, we used the method proposed by Brand-Williams et al. (1995) with modifications proposed by Zarban et al. (2009), and the ABTS radical was estimated according to the procedure proposed by Turoli et al. (2004). The frozen HM samples were thawed in water bath at the time of the analysis, according to the Ministry of Health (Brasil, 2015).

The results were expressed as mean and standard deviation of six replications. For normal distribution, the results were tested by analysis of variance (ANOVA). For significant interaction, time was broken down within each storage temperature using regression analysis at the $5 \%$ level of significance. Statistical analyses were performed using the software Statistical Package for Social Sciences (SPSS - version 18.0). 


\section{Results and discussion}

\subsection{Hygienic-sanitary quality of milk}

The Staphylococcus aureus count in the milk of the donors evaluated ranged from $5 \times 10^{1}$ to $2 \times 10^{3}(1.7$ and 3.3) CFU/ $\mathrm{mL}$ (Table 1). This microorganism is common in regions of the human body such as the nasal passages, throat, skin, and hair (Silva et al., 2010). According with Serra et al. (2013), the presence of pathogenic bacteria such as Staphylococcus aureus, Escherichia coli, Streptococcus faecalis, Enterobacter sakazakii, (â-hemolytic) Streptococcus pyogenes, species of Pseudomonas, Proteus and Salmonella is considered unacceptable for food or human milk.

Table 1. Means and standard deviations of the microbiological analyses of human milk extracted at home expressed in logarithms.

\begin{tabular}{cccccc}
\hline \multirow{2}{*}{ Donors } & \multicolumn{5}{c}{ Microorganisms } \\
\cline { 2 - 6 } & ${\text { S. } \text { aureus }^{* *}}^{*}$ CT $^{* * *}$ & CTT $^{* * *}$ & Mesophiles $^{* *}$ & Molds and yeasts $^{* *}$ \\
\hline M1 & $2.5 \times 10^{2} \pm 2.1 \times 10^{2}$ & $<0.3 \pm 0$ & $<0.3 \pm 0$ & $1.1 \times 10^{3} \pm 9.7 \times 10^{2}$ & $3.3 \times 10^{1}$ est. $\pm 3.3 \times 10^{1}$ \\
\hline M2 & $2 \times 10^{3} \pm 2 \times 10^{3}$ & $2 \pm 2$ & $<0.3 \pm 0$ & $1.1 \times 10^{4} \pm 3.3 \times 10^{3}$ & $2.2 \times 10^{3} \pm 1.5 \times 10^{3}$ \\
\hline M3 & $5.6 \times 10^{2} \pm 5.3 \times 10^{2}$ & $1.3 \times 10^{1} \pm 1.1 \times 10^{1}$ & $1 \pm 1$ & $3.2 \times 10^{3} \pm 2.7 \times 10^{3}$ & $2.8 \times 10^{1}$ est. $\pm 1.3 \times 10^{1}$ \\
\hline M4 & $*$ & $<0.3 \pm 0$ & $<0.3 \pm 0$ & $1.2 \times 10^{4} \pm 7.5 \times 10^{3}$ & $7.3 \times 10^{1}$ est. $\pm 4.8 \times 10^{1}$ \\
\hline M5 & $5 \times 10^{1} \pm 10^{1}$ & $<0.3 \pm 0$ & $<0.3 \pm 0$ & $2.7 \times 10^{2} \pm 1.2 \times 10^{2}$ & $3.5 \times 10^{1}$ est. $\pm 3.5 \times 10^{1}$ \\
\hline
\end{tabular}

M1: Mother 1; M2: Mother 2; M3: Mother 3; M4: Mother 4 and M5: Mother 5; S. aureus: Staphylococcus aureus; CT: Total coliforms; CTT: Thermotolerant coliforms; *Data not shown; ${ }^{* *} \mathrm{CFU} / \mathrm{mL} ;{ }^{* * *} \mathrm{MPN} / \mathrm{mL}$.

The yeast and mold count in the milk of the five donors ranged from $2.8 \times 10^{1}$ to $2.2 \times 10^{3}$ (1.5 to 3.3 ) $\mathrm{CFU} / \mathrm{mL}$ (Table 1). According Serra et al. (2013), yeast and fungi growth would indicate inadequate hygienic and sanitary conditions, especially due to the incorrect hand washing. These values are close to those found in the study by Novak et al. (2008), who evaluated the microbiological quality of 30 raw HM samples obtained from HMB donors of the Fernandes Figueira Institute. Their counts were around $10^{3} \mathrm{CFU} / \mathrm{mL}$, which may indicate possible flaws in the mothers or utensils hygiene used for extraction. As described by the Rede Nacional de Bancos de Leite Humano (2004), the presence of molds and yeasts disqualifies raw HM for consumption.

The total aerobic mesophiles counts ranged from $2.7 \times 10^{2}$ to $1.2 \times 10^{4}(2.4$ to 4.1$) \mathrm{CFU} / \mathrm{mL}$. Serra et al. (2013), registered that almost $40 \%$ of the samples had a growth of mesophilic bacteria $\geq 10^{5} \mathrm{CFU} / \mathrm{mL}$. Torres de Freitas et al. (2009) found bacterial growth in all the samples with no less than $10^{2} \mathrm{CFU} / \mathrm{mL}$, while Law et al. (1989) found $\leq 10^{8} \mathrm{CFU} / \mathrm{mL}$ in $25 \%$ of their samples, and Almeida Castanho Rozolen et al. (2006) verified growth of mesophilic bacteria lower than $2500 \mathrm{CFU} / \mathrm{mL}$ in $80 \%$ of the analyzed samples. These differences in the way of expressing tolerable levels of bacterial growth clearly reflect the lack of consensus about an acceptable level in breast milk.

According to the Rede Nacional de Bancos de Leite Humano (2004), when extraction is performed under correct hygienic-sanitary conditions, raw HM has a total count of microorganisms in the order of $10^{2} \mathrm{CFU} / \mathrm{mL}$. All the analyzed samples (Table 1) presented higher values, demonstrating, therefore, the necessity of reinforcing the good practices of collection with these mothers.

Contamination of HM by total coliforms ranged from 2 to $1.3 \times 10^{1}(0$ and 1.1$) \mathrm{MPN} / \mathrm{mL}$ (Table 1$)$. The evaluated milks of four mothers had thermotolerant coliform counts $<0.3 \mathrm{MPN} / \mathrm{mL}$; however, the milk of the mother M3 presented contamination of $1 \mathrm{MPN} / \mathrm{mL}$. The results of the present study differ from those reported 
by Novak et al. (2008), whose total coliform counts ranged from $10^{4}$ to $10^{6} \mathrm{CFU} / \mathrm{mL}$, and thermotolerant coliforms in the order of $10^{3}$ and $10^{4} \mathrm{CFU} / \mathrm{mL}$, indicating worse hygienic-sanitary conditions.

The great variability in relation to the contamination of the milks evaluated in the present study is noteworthy, which can be verified by analyzing the standard deviations (Table 1). The discrepancy in the Staphylococcus aureus counts of the mother M4 (which was not presented in Table 1) varied from $<10 \mathrm{CFU} / \mathrm{mL}$ est. (first collection) to $>150 \mathrm{CFU} / \mathrm{mL}$ est. (second collection). These values are probably due to the insufficient quality control adopted in relation to hygienic-sanitary procedures before, during and after extraction.

\subsection{Effect of freezing time and temperatures on the antioxidant capacity of human milk}

In relation to the total antioxidant capacity determined by the ABTS method, the pool of raw HM (before freezing) presented a mean value of $3079.88 \pm 280.38 \mu \mathrm{mol}$ Trolox $/ \mathrm{mL}$, close to that found by Sari et al. (2012), which was $3500 \mu \mathrm{mol}$ Trolox/mL. However, other studies (Hanna et al., 2004; Sari et al., 2012) found a lower value $(1600 \mu \mathrm{mol}$ Trolox $/ \mathrm{mL})$ compared to the present study. These differences may be related to HM packaging before and at the time of analysis. In the present study, there was no significant effect of temperature conditions and freezing time on the total antioxidant capacity of HM.

The present study evaluated the temperatures of $-8^{\circ} \mathrm{C}$ and $-18{ }^{\circ} \mathrm{C}$ due to the proximity to those obtained in domestic refrigerators and freezers, where the mothers store the extracted milk. In addition, we also tested a lower temperature $\left(-40^{\circ} \mathrm{C}\right)$ to have an estimate of stability when stored under laboratory conditions.

The results of the determination of the total antioxidant capacity by the DPPH method demonstrated that during the frozen storage time (2, 4, 8 and 15 days), the total antioxidant capacity of HM significantly reduced $(p \leq 0.05)$ at all freezing temperatures of studied $\left(-8^{\circ} \mathrm{C},-18^{\circ} \mathrm{C}\right.$ and $\left.-40{ }^{\circ} \mathrm{C}\right)$ (Figure 1). Nevertheless, at $-40{ }^{\circ} \mathrm{C}$ there was an increase in the total antioxidant capacity in the first days of storage and, later, presented a downward trend. We also observed that the lower the freezing temperature, the greater the preservation of the antioxidant capacity of stored HM.

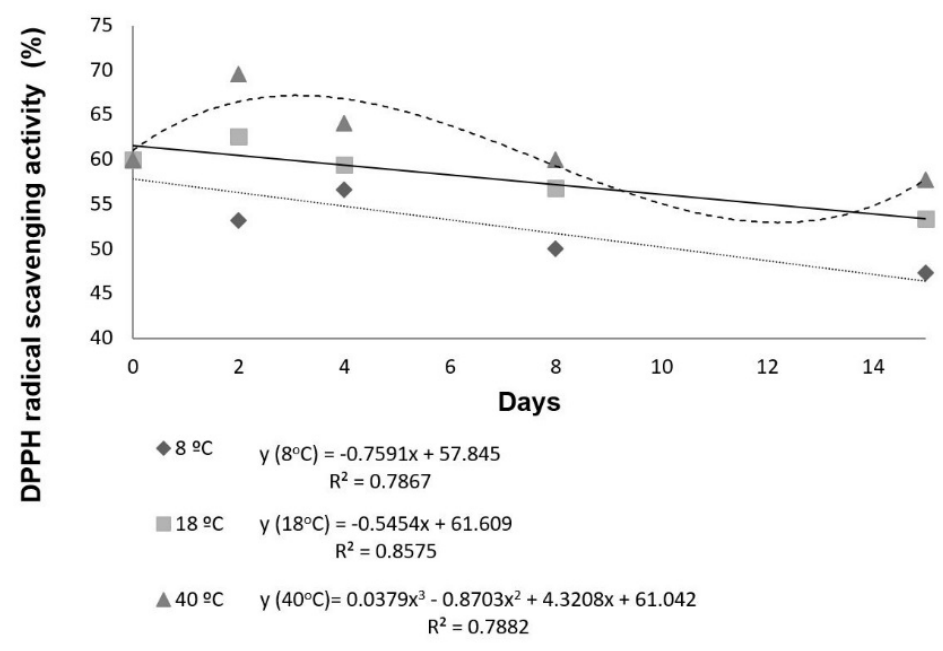

Figure 1. DPPH radical scavenger activity (\%) at different temperatures over frozen storage time.

The increase in total antioxidant capacity at two days of storage at $-40{ }^{\circ} \mathrm{C}$ may be related to the formation of ice crystals within the cell matrix that modify the permeability of cell membranes, increasing the exposure of the bioactive compounds present. Alanís-Garza et al. (2015) observed an increase of carotenoids in broccoli subjected to industrial freezing, and Olivera et al. (2008) observed an increase of flavonoids in frozen cabbages. 
It is known that the lower the freezing temperature, the lower the multiplication of microorganisms and the rate of enzymatic reactions, and the enzyme lipase, present in $\mathrm{HM}$, remains active up to $-20{ }^{\circ} \mathrm{C}$ (Turoli et al., 2004). As observed in the present study, it may be that at $-40{ }^{\circ} \mathrm{C}$ a lower release of free fatty acids occurs through the action of the lipase enzyme and, consequently, a lower amount of reactive oxygen substances, which would imply the higher antioxidant capacity (Ordóñez, 2005).

The study by Hanna et al. (2004) showed that $\mathrm{HM}$ frozen at $-20^{\circ} \mathrm{C}$ for 48 hours retained its antioxidant capacity with greater effectiveness in contrast to freezing for 7 days. Silvestre et al. (2010) have shown that significant reductions in the antioxidant properties of frozen HM occur over time, and such losses are lower at $-80^{\circ} \mathrm{C}$. Moreover, Buss et al. (2001) reported that the concentration of vitamin $\mathrm{C}$ reduces over the freezing time. This study determined an ideal HM storage time of up to one month to preserve vitamin $\mathrm{C}$ that acts on the renewal of endothelial function, the prevention of formation of nitric oxide during infections and lipid peroxidation (Weitzel et al., 2009), besides being responsible for part of the antioxidant capacity of HM.

With temperatures close to those evaluated in the present study, Miranda et al. (2004) reported that storage of $\mathrm{HM}$ at $-20^{\circ} \mathrm{C}$ for 10 days reduces the activity of glutathione peroxidase and increases its malondialdehyde content, which implies the reduction of antioxidant capacity.

Akdag et al. (2014) evidenced that the temperature $-80{ }^{\circ} \mathrm{C}$ preserved the antioxidant capacity for three months, evaluated by the FRAP iron reduction method. In contrast, Sari et al. (2012) reported a reduction in the antioxidant capacity of transition and mature milks after freezing at $-80{ }^{\circ} \mathrm{C}$ for two months. RamírezSantana et al. (2012) evaluated the effect of freezing colostrum at $-20^{\circ} \mathrm{C}$ and $-80{ }^{\circ} \mathrm{C}$ for 6 and 12 months on bioactive factors such as IgA, growth factors and cytokines (IL-6, IL-8, IL-10) and concluded that it can be stored at $-20^{\circ} \mathrm{C}$ or $-80^{\circ} \mathrm{C}$ for up to 6 months without significant losses of its immunological properties, once, after 6 months of freezing, the bioactive factors evaluated were significantly reduced.

Studies related to the effects of freezing on the antioxidant capacity of HM are still inconclusive about the best storage condition. Perhaps the use of different methods, handling and storage prior to the analysis are correlated with the variation in the results found in the literature, as well as the speed in the formation of ice crystals during freezing (Ordóñez, 2005). The freezing rate is related not only to exposure temperatures but to HM packaging, including the material and size of the vials used for storage. Therefore, later studies should be carried out with the purpose of evaluating the kinetics of freezing and its effects on the components of HM.

\section{Conclusion}

The present study showed that the HM samples presented inadequate hygienic-sanitary aspects, and it is relevant to reinforce the training on good manipulation practices for $\mathrm{HM}$ extraction. We conclude that freezing influences the total antioxidant capacity of HM and that over the course of storage time the losses become significantly greater. Furthermore, freezing at lower temperatures tends to preserve the total antioxidant capacity of stored HM.

\section{Acknowledgements}

To the Federal University of Ouro Preto and Coordenação de Aperfeiçoamento de Pessoal de Nível Superior (CAPES).

\section{References}

Akdag, A., Nur Sari, F., Dizdar, E. A., Uras, N., Isikoglu, S., Erel, O., \& Dilmen, U. (2014). Storage at $-80^{\circ} \mathrm{C}$ preserves the antioxidant capacity of preterm human milk. Journal of Clinical Laboratory Analysis, 28(5), 415-418. PMid:24652589. http://dx.doi.org/10.1002/jcla.21703 
Alanís-Garza, P. A., Becerra-Moreno, A., Mora-Nieves, J. L., Mora-Mora, J. P., \& Jacobo-Velázquez, D. A. (2015). Effect of industrial freezing on the stability of chemopreventive compounds in broccoli. International Journal of Food Sciences and Nutrition, 66(3), 282-288. PMid:25690928. http://dx.doi.org/10.3109/09637486.2015.1007451

Almeida Castanho Rozolen, C. D., Goulart, A. L., \& Kopelman, B. I. (2006). Is breast milk collected at home suitable for raw consumption by neonates in Brazilian Public Neonatal Intensive Care Units? Journal of Human Lactation, 22(4), 418-425. PMid:17062787. http://dx.doi.org/10.1177/0890334406293362

American Academy of Pediatrics (2003). Recommendations for care children in special circumstances: human milk. In L. K. Pickering (Ed.), Red Book: 2003 Report of the Committee on Infectious Diseases (26th ed., 117-123). Itasca: AAP. Retrieved in 2016, October 1, from https://www.aap.org/en-us/Pages/Default.aspx

Association of Official Analytical Chemists (2019). Official Methods of Analysis Microbiological Methods 2003.07 e 2003.11 (21th ed.). Gaithersburg: AOAC.

Berenhauser, A. C., Soares, D., Komora, N., De Dea Lindner, J., Schwinden Prudêncio, E., Oliveira, J. V., \& Block, J. M. (2018). Effect of highpressure carbon dioxide processing on the inactivation of aerobic mesophilic bacteria and Escherichia coli in human milk. Journal of Food, 16(1), 122-126.

Brand-Williams, W., Cuvelier, M. E., \& Berset, C. (1995). Use of a free radical method to evaluate antioxidant activity. Lebensmittel-Wissenschaft + Technologie, 28(1), 25-30. http://dx.doi.org/10.1016/S0023-6438(95)80008-5

Brasil. Ministério da Agricultura, Pecuária e Abastecimento. Secretaria de Defesa Agropecuária. (2019). Oficializa os Métodos Analíticos Oficiais para Análises Microbiológicas para Controle de Produtos de Origem Animal e Água (Instrução Normativa $N^{\circ}$ 62, de 27 de Novembro de 2019). Diário Oficial [da] República Federativa do Brasil, Brasília.

Brasil. Ministério da Saúde, Agência Nacional de Vigilância Sanitária - ANVISA. (2008). Banco de leite humano: funcionamento, prevenção e controle de riscos. Brasília: ANVISA.

Brasil. Ministério da Saúde. Secretaria de Atenção à Saúde. Departamento de Ações Programáticas Estratégicas. (2015). Cartilha para a mulher trabalhadora que amamenta (2. ed.). Brasília: Ministério da Saúde.

Buss, I. H., McGill, F., Darlow, B. A., \& Winterbourn, C. C. (2001). Vitamin C is reduced in human milk after storage. Acta Paediatrica (Oslo, Norway : 1992), 90(7), 813-815. PMid:11519987. http://dx.doi.org/10.1080/080352501750315753

Ding, J., Asula, M. Y., \& Tan, V. S. C. (2015). Analysis of the influence of processing on human milk's macronutrient concentrations. Neonatal Intensive Care, 28(2), 19-22.

Eglash, A., Simon, L., \& The Academy of Breastfeeding Medicine Wendy. (2017). ABM Clinical Protocolo 8: human milk storage information for home use for full-term infants, revised 2017. Breastfeeding Medicine, 12(7), 390-395. PMid:29624432. http://dx.doi.org/10.1089/bfm.2017.29047.aje

Friel, J. K., Friesen, R. W., Harding, S. V., \& Roberts, L. J. (2004). Evidence of oxidative stress in full-term healthy infants. Pediatric Research, 56(6), 878-882. PMid:15470194. http://dx.doi.org/10.1203/01.PDR.0000146032.98120.43

Grazziotin, A. L., Grazziotin, M. C., \& Letti, L. A. (2010). Disposal of human milk donated to a human milk bank before and after measures to reduce the amount of milk unsuitable for consumption. Jornal de Pediatria, 86(4), 290-294. PMid:20711545. http://dx.doi.org/10.2223/JPED.2014

Haiden, N., Pimpel, B., Assadian, O., Binder, C., Kreissl, A., Repa, A., Thanhäuser, M., Roberts, C. D., \& Berger, A. (2016). Comparison of bacterial counts in expressed breast milk following standard or strict infection control regimens in neonatal intensive care units: compliance of mothers does matter. The Journal of Hospital Infection, 92(3), 226-228. PMid:26850928. http://dx.doi.org/10.1016/j.jhin.2015.11.018

Hanna, N., Ahmed, K., Anwar, M., Petrova, A., Hiatt, M., \& Hegyi, T. (2004). Effect of storage on breast milk antioxidant activity. Archives of Disease in Childhood. Fetal and Neonatal Edition, 89(6), F518-F520. PMid:15499145. http://dx.doi.org/10.1136/adc.2004.049247

Keim, S. A., Hogan, J. S., McNamara, K. A., Gudimetla, V., Dillon, C. E., Kwiek, J. J., \& Geraghty, S. R. (2013). Microbial contamination of human milk purchased via the Internet. Pediatrics, 132(5), e1227-e1235. PMid:24144714. http://dx.doi.org/10.1542/peds.2013-1687

Laird, D. T., Lenarz, G., Scher, F. M., Graham, T. E., \& Reddy, R. (2004). Microbiological count methods: Standard methods for the examination of dairy products (Chapter 6 ). Washington: APHA.

Law, B. J., Urias, B. A., Lertzman, J., Robson, D., \& Romance, L. (1989). Is ingestion of milk-associated bacteria by premature infants fed raw human milk controlled by routine bacteriologic screening? Journal of Clinical Microbiology, 27(7), 1560-1566. PMid:2768443. http://dx.doi.org/10.1128/JCM.27.7.1560-1566.1989

Lindmark-Månsson, H., \& Åkesson, B. (2000). Antioxidative factors in milk. British Journal of Nutrition, 84(Suppl. 1), S103-S110. PMid:11242454. http://dx.doi.org/10.1017/S0007114500002324

Meng, T., Perrin, M. T., Allen, J. C., Osborne, J., Jones, F., \& Fogleman, A. D. (2016). Storage of unfed and leftover pasteurized human milk. Breastfeeding Medicine, 11(10), 538-543. PMid:27754716. http://dx.doi.org/10.1089/bfm.2016.0139

Miranda, M., Muriach, M., Almansa, I., Jareño, E., Bosch-Morell, F., Romero, F. J., \& Silvestre, D. (2004). Oxidative status of human milk and its variations during cold storage. BioFactors (Oxford, England), 20(3), 129-137. PMid:15665383. http://dx.doi.org/10.1002/biof.5520200302

Novak, F. R., \& Cordeiro, D. (2007). Correlação entre população de microrganismos mesófilos aeróbios e acidez Dornic no leite humano ordenhado. The Journal of Pediatrics, 83, 87-91.

Novak, F. R., Junqueira, A. R., Dias, M. S. P. C., \& Almeida, J. A. G. (2008). Sensorial analysis of expressed human milk and its microbial load. Jornal de Pediatria, 84(2), 181-184. PMid:18270644. http://dx.doi.org/10.1590/S0021-75572008000200016 
Obiajuru, I. O. C., Ikpeama, C. A., \& Elo-llo, J. E. (2017). Microbiological assessment and storage quality of expressed breast milk. International Journal of Medical, Pharmacy and Drug Research, 1(2), 5-9.

Olivera, D. F., Viña, S. Z., Marani, C. M., Ferreyra, R. M., Mugridge, A., Chaves, A. R., \& Mascheroni, R. H. (2008). Effect of blanching on the quality of Brussels sprouts (Brassica oleracea L. gemmifera DC) after frozen storage. Journal of Food Engineering, 84(1), 148-155. http://dx.doi.org/10.1016/j.jfoodeng.2007.05.005

Ordóñez, J. A. (2005). Tecnologia de alimentos: componentes dos alimentos e processos (Vol. 1, pp. 161-177). Porto Alegre: Artmed.

Perrin, M. T., Fogleman, A. D., Davis, D. D., Wimer, C. H., Vogel, K. G., \& Palmquist, A. E. L. (2018). A pilot study on nutrients, antimicrobial proteins, and bacteria in commerce-free models for exchanging expressed human milk in the USA. Maternal and Child Nutrition, 14(Suppl. 6), e12566. PMid:30592165. http://dx.doi.org/10.1111/mcn.12566

Ramírez-Santana, C., Pérez-Cano, F. J., Audí, C., Castell, M., Moretones, M. G., López-Sabater, M. C., Castellote, C., \& Franch, A. (2012). Effects of cooling and freezing storage on the stability of bioactive factors in human colostrum. Journal of Dairy Science, 95(5), 2319-2325. PMid:22541460. http://dx.doi.org/10.3168/jds.2011-5066

Rede Nacional de Bancos de Leite Humano. (2004). Normas Técnicas REDEBLH-BR para Bancos de Leite Humano: Ordenha: Procedimentos Higiênico-Sanitários. Rio de Janeiro: Fiocruz.

Ruiz, L., Espinosa-Martos, I., García-Carral, C., Manzano, S., McGuire, M. K., Meehan, C. L., McGuire, M. A., Williams, J. E., Foster, J., Sellen, D. W., Kamau-Mbuthia, E. W., Kamundia, E. W., Mbugua, S., Moore, S. E., Kvist, L. J., Otoo, G. E., Lackey, K. A., Flores, K., Pareja, R. G., Bode, L., \& Rodríguez, J. M. (2017). What's normal? Immune profiling of human milk from healthy women living in different geographical and socioeconomic settings. Frontiers in Immunology, 8, 696. PMid:28713365. http://dx.doi.org/10.3389/fimmu.2017.00696

Sari, F. N., Akdag, A., Dizdar, E. A., Uras, N., Erdeve, O., Erel, O., \& Dilmen, U. (2012). Antioxidant capacity of fresh and stored breast milk: is- $80^{\circ} \mathrm{C}$ optimal temperature for freeze storage? The Journal of Maternal-Fetal \& Neonatal Medicine, 25(6), 777782. PMid:21801121. http://dx.doi.org/10.3109/14767058.2011.592230

Serra, V. V., Teves, S., López de Volder, A., Ossorio, F., Aguilar, N., \& Armadans, M. (2013). Comparison of the risk of microbiological contamination between samples of breast milk obtained athome and at a healthcare facility. Archivos Argentinos de Pediatria, 111(2), 115-119. PMid:23568067.

Silva, N., Junqueira, V. C. A., \& Silveira, N. F. A. (2010). Manual de métodos de análise microbiológica de alimentos e água (4. ed., pp. 59-64). São Paulo: Livraria Varela.

Silvestre, D., Miranda, M., Muriach, M., Almansa, I., Jareno, E., \& Romero, F. J. (2010). Frozen breast milk at -20 degrees C and -80 degrees $\mathrm{C}$ : a longitudinal study of glutathione peroxidase activity and malondialdehyde concentration. Journal of Human Lactation, 26(1), 35-41. PMid:19759352. http://dx.doi.org/10.1177/0890334409342987

Tijerina-Sáenz, A., Innis, S. M., \& Kitts, D. D. (2009). Antioxidant capacity of human milk and its association with vitamins A and $\mathrm{E}$ and fatty acid composition. Acta Paediatrica (Os/o, Norway : 1992), 98(11), 1793-1798. PMid:19807706. http://dx.doi.org/10.1111/j.1651-2227.2009.01437.x

Torres de Freitas, A., Duran, Z., \& Rodríguez, C. (2009). Acidez titulable como control de calidad para la leche humana. Archivos Venezolanos de Puericultura y Pediatria, 73, 92-96.

Tsukahara, H. (2007). Biomarkers for oxidative stress: clinical application in pediatric medicine. Current Medicinal Chemistry, 14(3), 339-351. PMid:17305536. http://dx.doi.org/10.2174/092986707779941177

Turoli, D., Testolin, G., Zanini, R., \& Bellù, R. (2004). Determination of oxidative status in breast and formula milk. Acta Paediatrica (Oslo, Norway), 93(12), 1569-1574. PMid:15841763. http://dx.doi.org/10.1111/j.1651-2227.2004.tb00845.x

United States Food and Drug Administration. (2015). Grade "a" pasteurized milk ordinance. Rockville: Food and Drug Administration, U.S. Department of Health \& Human Services.

Wehr, H. M., \& Frank, J. F. (2004). Standard methods for the examination of dairy products (17th ed.). Washington: American Public Health Association. http://dx.doi.org/10.2105/9780875530024.

Weitzel, L. B., Mayles, W. J., Sandoval, P. A., \& Wischmeyer, P. E. (2009). Effects of pharmaconutrients on cellular dysfunction and the microcirculation in critical illness. Current Opinion in Anaesthesiology, 22(2), 177-183. PMid:19307892. http://dx.doi.org/10.1097/ACO.0b013e328328d32f

Zarban, A., Taheri, F., Chahkandi, T., Sharifzadeh, G., \& Khorashadizadeh, M. (2009). Antioxidant and radical scavenging activity of human colostrum, transitional and mature milk. Journal of Clinical Biochemistry and Nutrition, 45(2), 150-154. PMid:19794922. http://dx.doi.org/10.3164/jcbn.08-233

Funding: Coordenação de Aperfeiçoamento de Pessoal de Nível Superior (CAPES). 